\title{
The Thorns of Trauma: Torture, Aftermath, and Healing in Contemporary Fairy-Tale Literature
}

\author{
Jeana Jorgensen
}

check for updates

Citation: Jorgensen, Jeana. 2021. The Thorns of Trauma: Torture,

Aftermath, and Healing in

Contemporary Fairy-Tale Literature.

Humanities 10: 47. https://doi.org/ 10.3390/h10010047

Received: 31 December 2020

Accepted: 3 March 2021

Published: 11 March 2021

Publisher's Note: MDPI stays neutral with regard to jurisdictional claims in published maps and institutional affiliations.

Copyright: (C) 2021 by the author. Licensee MDPI, Basel, Switzerland. This article is an open access article distributed under the terms and conditions of the Creative Commons Attribution (CC BY) license (https:/ / creativecommons.org/licenses/by/ $4.0 /)$.
Department of History and Anthropology, Butler University, Indianapolis, IN 46208, USA; jsjorgen@butler.edu

\begin{abstract}
While classical fairy tales do not portray much depth of suffering, many contemporary fairy-tale retellings explore trauma and its aftermath in great detail. This article analyzes depictions of trauma in fairy tales, utilizing as a primary case study the "Beauty and the Beast" retelling $A$ Court of Thorns and Roses by Sarah J. Maas, arguing that this text provides a scientifically accurate representation of trauma and its aftermath, thereby articulating the real in fairy tales. Further, this article classifies that work as not simply a "dark" fairy tale (a contentious term that invites rethinking) but rather as fairy-tale torture porn, in a nod to the horror genre that foregrounds torture, surveillance, and the disruption of bodily boundaries and safety. However, the text's optimistic account of healing is uniquely relevant in a time of widespread trauma due to a global pandemic, thereby demonstrating that fairy tales remain germane in contemporary contexts.
\end{abstract}

Keywords: fairy tales; trauma; darkness

\section{Introduction}

For centuries, fairy tales have captivated audiences with their wondrous descriptions of magical items, quests, royalty, and happy endings. Yet a happily ever after is meaningless without the conflict and strife that precedes it; a "rags-to-riches" storyline necessitates rags before the riches can be earned or gifted. If conflict-even trauma-is at the heart of all narrative, including fairy tales, then it is worth asking how various narrative genres depict trauma and its aftereffects. Though fairy tales are often called wonder tales, tales that specifically deviate from reality, using trauma as a lens is one way in which we see reality in fairy tales: tales of magic that nonetheless contain a human core and emotional truths.

In the first sections of this paper, I establish a baseline for the depiction of trauma and describe the changes I see in how contemporary fairy-tale adaptations depict and handle trauma, both as a departure from those representations in classical/traditional fairy tales from both literary and oral tradition, and as a more recent shift as fairy-tale retellings branch out into their own sub-genres, some more graphically inclined than others. I term this shift "fairy-tale torture porn", in a nod towards a related genre in horror film and provide examples in fairy-tale literature. In the next section of this paper, I focus on a specific case study: the traumatic torture and eventual recovery of the fairy-tale heroine Feyre in Maas's (2015) A Court of Thorns and Roses series, which begins as a retelling of "Beauty and the Beast" (ATU tale type 425C).

Writing this essay in 2020 - a year when a global pandemic has left many people traumatized in a variety of ways-I would like to draw attention to the importance of understanding trauma as it manifests in our lives and in our expressive culture, whether folklore, literature, pop culture, or texts situated at their margins. In the early days of the global pandemic, many Americans binge watched Netflix shows such as Tiger King, consuming narratives of drama, intrigue, and abuse; as the pandemic progressed, creative outlets such as sourdough baking became popular. While everyone processes trauma differently, and the above examples might well range from distracting and numbing techniques to actively creative engagements, I argue that it is key to understand what trauma is and how it functions in our lives as well as our narrative consumption, no matter 
how fantastical those narratives might appear on the surface. This essay is one contribution to that conversation.

\section{Trauma in Reality; Trauma in Fairy Tales}

In order to establish the real in fairy tales, where trauma is "the real", I will first provide an overview of scientific and medical findings about trauma, findings that establish what trauma is, how it manifests in those who experience it, and how it is most likely to heal. While cultural differences obviously impact how people experience, perceive, communicate about, and treat trauma, as with any aspect of embodiment, there are some constants based on shared human neurological structures, even as these structures may be shaped by the embodied variables of different times and places.

Trauma, in brief, is an overwhelming experience of an existential threat, to oneself or to others that one witnesses. Medical doctor and psychiatry professor Bessel Van der Kolk describes trauma as "by definition, unbearable and intolerable" (1). Trauma encompasses experiences that are not merely unpleasant or painful but feel and/or are world shattering and life destroying. Traumatic incidents of various degrees of severity may stick with us or may be shrugged off. Trauma also refers to the long-term effects of the traumatic incident, and how those effects mold us: "trauma is not just an event that took place sometime in the past; it is also the imprint left by that experience on mind, brain, and body" (Van der Kolk 2014, p. 21). Another medical doctor and psychiatrist (Gordon 2019), reminds readers that "Our initial responses to physical threats, abuse, and loss are healthy and designed to preserve us" (p. 27). The problem is that "these responses can persist even when the actual trauma is long over", when "Our large, complex brains may replay an endless loop of traumatic memories-of loss or abuse, of damage and helplessness, and of the pain and shame that go with them" (p. 29). Trauma can thus linger, having psychological and physiological effects upon those experiencing it.

Misconceptions about trauma abound, due in part to how it has been conceptualized and studied. Going to war and surviving sexual assault are not the only traumatizing experiences in the world, though veterans and domestic abuse and rape survivors are heavily studied, as Van der Kolk notes in the case studies of his book The Body Keeps the Score that informed his approach to trauma in recent decades. Other traumatic events are quite common, as (Gordon 2019) notes:

Having a life-threatening illness, a long-term disability, or chronic pain is traumatic. So is caring for someone with these conditions.

Poverty is traumatizing, and so are racism and gender discrimination.

Loss of a loving relationship is deeply traumatizing. So is the loss of a job that gave our lives meaning and purpose.

And all of us, if we live long enough, will have to contend with the trauma of losing loved ones, and with old age, physical frailty, and death. (p. 2)

Identifying these shared life events as potentially traumatizing is an important move because it shifts the conversation from focusing on the highly visible and extreme forms of trauma (military conflict; sexual assault) to chronic stress and trauma that can have debilitating effects. At the same time, it is important not to overemphasize just how debilitating the lingering effects of trauma might be. Gordon encourages readers to challenge one dangerous misconception about trauma, that it "is an unmitigated disaster, causing permanent emotional crippling, requiring never-ending treatment, severely limiting the lives of those who've experienced it" (1). Experiencing trauma does not mean one is forever broken or abnormal; it may be a longer path to restore oneself to an existence not dominated by trauma, but it is possible, utilizing (among other things) healing modalities that will be discussed further below.

Trauma has been a regular theme in traditional fairy tales, even if it tends not to cohere as a recognizable motif or a structural plot point. It is not as though Propp ([1928] 1968) devotes one of his 31 functions to rape or assault; we might infer that sexual assault is 
a villainous act when it happens, but structurally it is not treated as a villainy as per Propp 's ([1928] 1968) definition of fairy-tale plot elements, with a few exceptions. Basile's seventeenth century version of ATU (or Aarne-Thompson-Uther, a numerical system devised by folklorists to categorize international folktale and fairy-tale plots) 410, "Sleeping Beauty", titled "Sun, Moon, and Talia", features the king who stumbles upon her sleeping bower raping her, but this is framed as what actually disenchants her, rather than as the initial villainy or curse that commences the plot. As far back as the classical roots of the fairy-tale genre (Rowe 1989) makes a strong case that Philomela, raped by her brotherin-law in Ovid's Metamorphoses, uses weaving as a way to tell her story, since he cut out her tongue and she can no longer speak (1989). This is congruent with contemporary understandings of how trauma can literally rob us of the ability to speak, given that it can disable parts of the brain during flashbacks, such as Broca's area, that govern language (Van der Kolk 2014, p. 43). One of the few instances where an assault is central to the tale's plot structure is in tale type $672 C^{*}$, "Testimony of the Serpent", summarized in the international tale type index: "A woman who owns (is friendly with) a magic serpent is raped by a prince. The woman asks the serpent, who witnessed the act of violence, to testify that the prince should marry no one else ... When the prince is about to marry a beautiful princess, the serpent twists itself about his neck" (Uther 2004, vol. 1, p. 370). Usually, this results in the prince being coerced into marrying the woman he had raped, which is structurally a happy ending.

I am wary, too, of conflating trauma with sexual trauma as mentioned above, given that there are many types of experience that can be traumatizing. However, the structural pattern seems to stand: if a character is not losing family or parents as part of Propp 's ([1928] 1968) first eight functions, then they are not likely to encounter a major, traumatic loss later in the tale's structure (or if a loss occurs, it is not framed as a major one; treacherous family members or suitors may die, but the protagonist seems unaffected by these events). Or, if the villain is punished in a particularly traumatic way-drawing examples solely from the Grimms, as when birds peck out Cinderella's stepsisters eyes at her wedding, or when Snow White's stepmother must dance herself to death in red hot iron shoes, or when the princess / goose girl's rival is thrown into a nail-studded barrel—then said suffering is portrayed as justified because it is righteously inflicted. We rarely receive an internal perspective on these violent acts (unless contemporary writers retell fairy tales from these neglected perspectives), and they remain structurally tethered to the final few functions of each tale, seen as fitting punishments for false brides, wicked stepmothers, and villains. However, it is worth noting briefly that evil women are punished in the classical tales much more frequently than treacherous men; Tatar ([1987] 2003) writes of the demise of the "stepmother's reign of terror" in the Grimms' tales, often depicted in "graphic and morbid detail" (p. 148) whereas negligent fathers are forgiven or forgotten and abusive men are generally rare outside of Bluebeard or Robber Bridegroom characters.

In many cases, however, trauma as we would recognize it simply seems to not exist in fairy tales. Max (Lüthi F) famously claimed: "mutilations call forth no expressions of physical or psychological suffering. Tears are only shed if this is important for the development of the plot" (p. 13). He uses examples such as the Grimms' tale "The Seven Ravens", where the sister cuts off her littlest finger to open the glass mountain where her enchanted brothers await. Lüthi (1982) observes that this happens "without the slightest indication of physical or psychological distress" (p. 13). We thus know that most characters in fairy tales are depthless, not showing the agony that they may feel. This claim of course is not universal, nor has it gone uncontested; as I have asserted, drawing on both fairy-tale scholarship and the scholarship of trauma, incest, and sexual assault, the heroine in ATU 510B, after escaping her father's incestuous advances, in many versions acts in ways that seem "psychotic" and which correspond to the symptoms found in female incest survivors, including guilt, shame, and anxiety (Jorgensen 2012, p. 109). Still, Lüthi's claim stands: while the heroine in 510B engages in behaviors that correspond to real-life manifestations of trauma, she does not seem terribly troubled while doing so. 
Perhaps the perception that fairy tales do not depict trauma also originates in the sanitization of the genre, the notion that fairy tales are "for" children. While the history of fairy tales is long and complex, scholars generally agree that the tales were mostly told/written by and for adults in documented periods such as the 1500s and 1600s in Italy and the late 1600s in France: "they were not told or written for children" (Zipes, Fairy Tale as Myth, p. 23). This association came later, as the genre was increasingly codified as an ideological vehicle for socializing children around the eighteenth century (Zipes, Fairy Tales and the Art of Subversion, p. 2), continuing with the Grimms' editing of subsequent editions of their tales, wherein they "carefully eliminated those passages they thought would be harmful for children's eyes" (p. 62). And, of course, there is the influence of Walt Disney and his fairy-tale films, which have become increasingly child coded and partake in myriad products aimed at children: mass-market films, film sequels, books, toys, dolls, and so on.

Trauma is present in many fairy-tale retellings, and has multiple effects on those who suffer it. The heroines of some contemporary retellings turn to violence to avenge the wrongs they have suffered, as analyzed in D'Amore's (2017) work, which touches on films like Snow White and the Huntsman and Hansel and Gretel: Witch Hunters. Similarly, Bonikowski (2019) argues that retellings of ATU 720, "The Juniper Tree", address the trauma of the primal scene, modified here to extend beyond Freud's original use of the term to mean "an unrepresentable trauma within the relationships between parents and children" (p. 236). This tale in particular "dramatizes the relationship between powerful parents and vulnerable children" (p. 238), and retellings of it "show how the excesses of the tale point to an unrepresentable trauma and therefore can be used to stand in for traumatic experiences that resist representation" (p. 243). This approach is particularly in line with literary trauma theory, which rests on teasing out the contradictions between narrativization and "an experience or event which overwhelms the individual and resists language or representation" as (Whitehead 2004) attests in Trauma Fiction (p. 3). Summarizing the early works of trauma theory innovator Cathy Caruth, Whitehead notes that "literary fiction plays a crucial role in providing the reader with a narrative which is not straightforwardly referential" (p. 13). One of the reasons I have selected the text A Court of Thorns and Roses (Maas 2015) to analyze is that it is straightforwardly referential, and its use of the fantastic allows for experiences and representations not possible in mimetic literature, much of which seems to have informed literary trauma theory.

As noted above, traumatic experiences resist representation for neurological reasons that doctors and scholars are beginning to better understand. Before analyzing my main case study, we shall follow the trail of breadcrumbs to linger over recent fairy-tale retellings that depict trauma, especially those texts that are explicitly traumatic, verging on if not outright representing torture.

\section{Tales Exploring Trauma: "Dark" Tales Both Old and New}

As established above, fairy tales have always attended to trauma, though in subtle ways due to the stylistic constraints of the genre as well as the two-century-long association of the genre with innocent childhood. Here, I assert that retellings and adaptations from recent decades have made this implicit focus on trauma more explicit, with a grisly and morbid devotion to aspects considered "dark" and gruesome, and further, I argue that this shift has arisen in response to real-world feminist concerns with sexual violence and trauma. This groundwork will then allow me to examine how this phenomenon plays out in a mainstream - in fact best-selling — series based on "Beauty and the Beast" (ATU 425C).

Why fairy tales, why trauma, and why now (or if not now, starting a few decades prior)? Much of Joosen's (2004) work is concerned with how "tales retold from a feminist perspective often display the same issues and stages that feminist criticism has dealt with during the past 30 years" including criticizing how women are portrayed in patriarchy (pp. 5-6). While Joosen (2004) has worked on the intertextual influence of psychoanalysis and feminism on fairy-tale retellings, I would argue that trauma scholarship (both feminist and medical in orientation) has also been on the rise in recent decades, and this too surely 
has had an influence on fairy-tale retellings. While all "waves" of feminism have been implicitly absorbed with understanding and ending violence against women, the third wave especially began to focus on explicit issues of consent and intersectionality, and trauma-informed language began to be more common. Hence, according to Joosen's (2004) model of mutual intertextual influence, it would make sense to see fairy-tale retellings echo this concern with trauma and its aftermath. Trauma, of course, is not always sexual in nature, and thus other fairy-tale retellings that explicitly address trauma include works on the Holocaust such as Yolen's (1995) novel Briar Rose (which uses "Sleeping Beauty" intertexts to reveal a family member's memories of surviving an extermination camp) and Morrison's (2012) Home (which uses "Hansel and Gretel" intertexts to address the intergenerational trauma inflicted by white supremacy in the U.S., analyzed in Visser 2016).

Early fairy tales that we might call traditional or canonical-those that contain the genre's classical roots like tales by Straparola and Basile, as well as those that have become standard fare, like ones by Charles Perrault, the Grimms, and Hans Christian Andersen-of course contain exceedingly violent acts. (Tatar [1987] 2003), for example, wrote an entire book on the premise that "fairy tales dwell on pain and suffering rather than on blissful happiness" (p. xxxii), focusing on the Grimms' collection. However, due in part to the sanitization fairy tales underwent as an integral part of Western children's literature and due to the Disneyfication process, this more violent heritage has not been part of the mainstream conception of fairy tales for some time. That changed in part due to the "Carter generation" in the 1960s and 1970s reinventing literary fairy tales to flesh them out, give backstory to less-understood and less-sympathetic characters, and to explore the sexy and violent themes that were less well-known. "Dark" fairy tales such as these and their successors have been in vogue for a couple of decades, birthed in literary and artistic circles and slowly becoming more mainstream. Scholars use the term as well; Wood (2006), for example, argues that the "darkness" in Hans Christian Andersen's tales depicts pain and sorrow, yes, but also gives both adults and children the ability "to recognize the truth of the pain that others seek to hide ... [to] produce works of exceptional artistry and beauty that are both satisfying in their sorrow and troubling in the questions that they raise" (p. 204). Even Jack Zipes uses the term, stating for example that Jean Cocteau's merit as a filmmaker, exemplified in La Belle et la Bête, was "to bring out the dark side of the fairy tale" (Fairy Tale as Myth, p. 44). The term is ubiquitous, also widely used to describe a variety of genres based on their grim or gritty tropes-dark fantasy, dark comedy, and so on.

At risk of stating the obvious, calling something a "dark" fairy tale is problematic for a variety of reasons, which is one motive for my introduction of an alternate term in order to describe a specific subset of fairy-tale retellings that heighten the sense of trauma by graphically depicting acts of torture. While colors on the spectrum and the range of tones from light to dark do not inherently have meaning, they can and do acquire symbolism. Various global mythologies have associated light/fair coloring with inherent goodness and dark/brown/black coloring with evil (Berne 1959), while within fairy tales specifically, dark skin is often used to connote low status and meanness, as with the many black slave girls who misbehave in the Tale of Tales (Basile and Canepa 2007) and as with the Grimms' tales that showcase characters with black skin who bear it either as punishment or as symbol of racial and colonial (negative) connotations (Schmiesing 2016). Indeed, in the related area of scholarship on speculative fiction, scholars use the adjective "dark" to signal precisely how race inflects storytelling; the work of (Thomas 2019) on "the dark fantastic", or "the role that racial difference plays in our fantastically storied imaginations" (p. 7) exemplifies this usage. Given the ascendance of scientific categories of race and racism in recent centuries, and the negative connotations of dark skin in white supremacist societies, uncritically labeling something dark (beyond the denotative meaning of the word as in shadowed, unlit) thereby is not a neutral act.

Another problem with the term "dark" fairy tale is that while it evokes racist ideologies on the one hand, it is quite vague on the other hand. Many fairy tales that are reworked into literary forms display increasing realism; is this realism itself dark? Concurrent 
with trends in children's and young adult fantasy literature in the 1980s and 1990s that bowed to the influence of "social realism" and "would tend to be more grim or violent" (Levy and Mendlesohn 2016, p. 161), many fairy-tale retellings in adjacent literary genres display some of these same markers of grim and violent social realism. Michael Levy and Farah Mendlesohn suggest "bitter" as a replacement for "dark", in that pointing to themes of "disappointment, bitterness, and desolation" (p. 211) seems to better characterize the plots in which these characters find themselves enmeshed. Levy and Mendlesohn name a number of fairy-tale retellings in their analysis (such as Gail Carson's Ella Enchanted and McKinley's (1993) Deerskin), thereby drawing attention to patterns of suffering that bridge fairy-tale literature and young adult literature more generally, patterns with more nuance than simply being "dark". Other adjectives, like grim and Gothic, may also do well to capture some of the associations that many "dark" fairy tales contain (one particularly Gothic trope is the vampire, and this is seen in fairy-tale retellings that posit the character Snow White as a vampire, as in "Red as Blood" by Lee 2016 and "Snow, Glass, Apples" by Gaiman 1998).

Crossing yet more genres, certain "dark" fairy tales are labeled as such due to their resemblance to horror. Tatar ([1987] 2003) characterizes Anne Sexton's poems in Transformations (Sexton 1971), particularly "Hansel and Gretel", which contains not only references to the to-be-expected theme of child-abandonment but also the Holocaust, as being "among the first to mingle fantasy with horror" (p. xx). Other scholars have noted connections between horror film and fairy tales, suggesting for instance that horror films can be productively read in fairy-tale terms regardless of whether they are explicit retellings (Rankin 2007) and that fairy-tale heroines' journeys can provide a model for understanding horror films' treatment of female characters, both those that conform to patriarchal models and those who do not (Short 2006). The connections between fairy tale and horror are thus numerous, and productive in both creative and scholarly contexts. Indeed, these connections as well as the increasing popularity in both genres may reflect a social function these genres serve, perhaps working through violence in times of increasing violence (though a detailed exploration is beyond the purview of this paper).

To categorize the more extreme versions of the "dark" or grim/bitter fairy-tale phenomenon, I thereby coin the term "fairy-tale torture porn", in a nod towards a horror subgenre alternately called torture porn, splatter film, and splatter punk. It is worth noting that these terms are not necessarily interchangeable although they may function as such in search engines; splatter punk specifically "aimed to shock, generally through displays of corporeal transgression encompassing anything from extreme mutilation and transformation to mutation or severe body modification and graphic sex" (Reyes 2014, p. 28). Both splatter punk and torture porn may be considered expressions of body horror, or even extensions of the Gothic (Reyes 2014), though they draw on slightly different tropes and emerge in different time periods, with torture porn being a more recent innovation. Aaron Michael Kerner characterizes the torture porn genre as a uniquely American response to post-9/11 social anxieties, with one of its key features being "that its plots are based in 'reality' - its characters are set in a mundane world where horrific things happen, perpetrated by flesh-and-blood mortals" (p. 23). Kerner argues that some of the main tropes of the genre include the idea that nowhere is safe, not even domestic spaces, and other key elements are rituals, riddles, puzzles, and games (pp. 25, 29-30). As will be seen below, A Court of Thorns and Roses (Maas 2015) utilizes these motifs in addition to highly graphic violence and torture. With a slightly different, though complementary, focus, Xavier Aldana Reyes argues that torture porn uses "a lens that is inherently gothic" (p. 123) and thus has roots that predate the heightened sense of surveillance and biopolitical punishments emerging from post-9/11 American culture. And in contrast to other horror genres which might focus on the sexualization of female victims, torture porn (which, granted, does still have "porn" in the title, indicating the genre's emphasis on voyeurism and the "money shot" of meaty parts, more geared towards violence and bodily violation than sexual penetration; see Kerner 2015, pp. 45-46) does not necessarily gender its victims: 
"Regardless of the gender, victims in torture porn typically endure extended torment and in fact might even live through their ordeal, but they usually remain mentally and physically scarred for life" (Kerner 2015, p. 45). Combining these scholarly insights, I argue that we may productively apply the label of fairy-tale torture porn to those works that not only depict graphic torture and violence but which revel in its representation and also have elements of the Gothic, finding horror in the mundane and exploring the extremes of bodily transgression. The characters in fairy-tale torture porn will emerge with significant trauma and scars, indicating, again, that this category of work differs meaningfully from both classic and retold fairy tales where the aftermath of the conflict is not mentioned. One commonality between the horror genre of torture porn and fairy-tale torture porn is that both types of texts are not always taken seriously by scholars (especially relevant given that A Court of Thorns and Roses (Maas 2015) has much in common with the often-stigmatized commercial genres of romance and fantasy literature), while one disjuncture between the horror genre and the fairy-tale retelling genre would be that fairy tales, rooted in magic and optimism, allow more space for healing in the aftermath of the trauma, which will be seen in my analysis of A Court of Thorns and Roses (Maas 2015).

Indeed, a variety of recent fairy-tale works display these traits. Retellings of "Sleeping Beauty" / "Briar Rose" especially trend towards torture porn, detailing the assault of the princess, the horror of the domestic space and lack of safety anywhere, and the ensuing trauma, turning readers into voyeurs. Examples include "She Sleeps in a Tower" by (Lee 1995) and "Briar Rose (Sleeping Beauty)" by Anne Sexton. Retellings of ATU 510B, due to the source text's focus on incest, sometimes go in graphic directions with the princess's father raping her, either lacking a happy ending (as in Yolen's (1995) "Allerleirauh") or depicting the princess struggling through her trauma to survive it and reshape her life beyond it (as in McKinley's (1993) Deerskin). The graphic novel series Grimm Fairy Tales serves up lascivious fairy-tale retellings with near-nudity and gore, with a focus on mistreated characters getting revenge, thereby meeting some of the qualifications to be considered torture porn (Tyler et al. 2006). One notable recent (2014) example of what I would term fairy-tale torture porn is the novel Princess of Thorns by (Jay 2014), wherein the protagonist, Aurora, is the daughter of a Sleeping-Beauty-type character who is gifted/cursed with supernatural strength as well as the ability to make any man who kisses her essentially a mindless servant. When she curses the person she falls in love with by psychically enslaving him, she uses this as a ploy to try to retake her kingdom by posing as his captive and ordering him to physically abuse her on the way to the castle, in order to make the deception believable. And he complies, mercilessly binding her: "The chapped skin at my wrists has torn open, blood oozes down my palms to my fingers, and a strange heat licks at my wrists. I suspect my wounds are becoming toxic and that I will fall into a fever if they aren't treated soon" (pp. 323-24). Aurora is being both physically and emotionally tortured, suffering at the hands of someone she cares about but whom she has (apparently) irreparably damaged by removing his free will. Later, when he is disenchanted, he accuses her of "punishing yourself, and using me to do it" (p. 362). The elements of both physical and emotional torture, the lack of safety, and the visceral depiction of pain all combine to make Princess of Thorns not merely a "dark" or bitter fairy tale, but one which qualifies as fairy-tale torture porn.

\section{A Court of Thorns and Roses as Fairy-Tale Torture Porn}

Published in 2015, A Court of Thorns and Roses by Maas (2015) is the first book in a New York Times bestselling series that encompasses fairy-tale retelling, fantasy literature, and young adult (YA) literature, though it has also been classified as New Adult, meaning that it is intended for a slightly older (perhaps even adult) audience. There has not been much scholarship on the work to date, though there have been many meta discussions in fandom ("meta" meaning fan criticism/critique/interpretation, much of it approaching scholarly analysis in depth; see (Sarahviehmann 2016a, 2016b) for instance). The novel was selected for analysis here because it reflects much of the "dark" turn in recent fantasy literature and 
popular culture (such as the book and television series Game of Thrones, often described as grim and gritty) while still clearly building on fairy tale plots and intertexts and utilizing elements of torture porn (violence, surveillance, and so on) to depict the main character's traumatic experiences.

The main fairy-tale intertext in the novel is "Beauty and the Beast", ATU 425C, wherein the (human) Feyre functions as the beauty to the beastly (fae or faerie) Tamlin. However, "Sleeping Beauty / Briar Rose", ATU 410, offers clear intertexts as well, both in the novel's title containing references to roses and thorns, and the various ways in which Feyre is locked away and immobilized. In the subsequent novels in the series, A Court of Mist and Fury (Maas 2016) and A Court of Wings and Ruin (2017), Feyre comes to terms with the trauma she has endured as well as the powers it has bestowed upon her. Though Feyre is tortured in a fairy-tale way-she is given three tasks to complete in order to disenchant her beastly lover-the graphic nature of the torture is unique and a qualifier to labeling the work fairy-tale torture porn. Further, Feyre's path to healing after the torture is also significant in terms of its scientific accuracy, which may have real-world parallels for readers with their own trauma.

Though it may sound extreme to state, Feyre is indeed tortured. Rhysand, a character who later confesses his love for Feyre, describes what he saw thus: "When she [Amarantha] started torturing you, something snapped in a way I couldn't explain, only that seeing you bleeding and screaming undid me" (Mist and Fury, Maas 2016, p. 526). Though Feyre is tortured more than once, Rhysand refers here specifically to the final trial that Feyre endures. She does not survive, a point that will be addressed later (and one which reinforces the application of the term fairy-tale torture porn).

At the novel's start, Feyre kills a fae wolf that came over the wall separating human and fae lands. Her life is forfeit, though Tamlin (the Beast) kidnaps her rather than killing her, and they slowly develop feelings for each other. When Feyre realizes that Tamlin was enchanted by the evil queen Amarantha, Feyre goes to Amarantha's court to try to save him. Amarantha makes the following deal: "You complete three tasks of my choosing-three tasks to prove how deep that human sense of loyalty and love runs, and Tamlin is yours" (Thorns and Roses, p. 301). Facing off a female protagonist against a female antagonist is another fairy-tale move, as fairy-tale characters are often pitted against same-gender opponents; further, Feyre is given interim tasks such as sorting lentils from the ash, clearly a reference to the Grimms' "Cinderella" (Thorns and Roses, p. 339). When Feyre agrees to the bargain, Amarantha has some of her servants beat Feyre, initiating her into this traumatic time: "I think there were three of them, and I became their punching bag-passed off from blow to blow, my bones screaming in agony. Maybe I was screaming in agony, too" (Thorns and Roses, p. 303). One of the reasons why Feyre survives after this beating and the subsequent task (to kill a giant monster) is that rival fae High Lord Rhysand strikes a bargain with Feyre: he will heal her arm, which is on the verge of deadly infection, in exchange for a bargain that binds Feyre to visit his Court for one week every month. This bargain is sealed in ink, a tattoo etched onto her left forearm and hand, which initially seems to Feyre a diabolical plan meant "to hurt Tamlin" (Thorns and Roses, p. 336). However, the bargain between them also creates a bond that lets Rhysand and Feyre sometimes sense one another's emotions and thoughts.

The second and third tasks are less physical in nature, though these still count as a form of torture and compound Feyre's overall trauma. In the second task, Feyre is placed in a chamber with a ceiling that will lower and crush her-and her fae ally/friend, Lucien-if she does not solve a riddle and pull the correct lever. As observed above, the horror film genre of torture porn often involves riddles and rituals. However, Feyre is close to illiterate. The stress of the situation and the humiliation of not being able to decipher a simple text are both traumatic for Feyre; she is only saved due to the magical bond with Rhysand, which allows him to guide her hand to the correct lever. While Feyre holds up during the ordeal, the intensity of the existential threat overwhelm her in her cell: 
I wept for hours. For myself, for Tamlin, for the fact that I should be dead and had somehow survived. I cried for everything I'd lost, every injury I'd ever received, every wound-physical or otherwise. I cried for that trivial part of me, once so full of color and light_- now hollow and dark and empty.

I couldn't stop. I couldn't breathe. I couldn't beat her. She won today, and she hadn't known it. (Thorns and Roses, p. 367)

Feyre's utter despair consumes her. Again, it is worth noting that simply crying a lot does not necessarily indicate a trauma response; what makes this scene important in this analysis is that Feyre's tears do not help her complete the physiological stress cycle and move on to feeling calmer and back in control of her life. Instead, she loses all hope and remains stuck in the past, which is a classic trauma symptom (see Gordon 2019, p. 55 for example). Indeed, she is physiologically anchored in the past, still experiencing those moments of fear when she was almost killed by being crushed:

The walls closed in-the ceiling dropped. I wanted to be crushed; I wanted to be snuffed out. Everything converged, squeezing inwards, sucking out air. I couldn't keep myself in my body - the walls were forcing me out of it. I was grasping for my body, but it hurt too much each time I tried to make the connection. (Thorns and Roses, p. 367)

Reliving the past in highly sensory ways and being unable to inhabit one's body in the present moment are both signs of trauma. The latter is often called dissociation and is a common symptom of unresolved trauma. Due to the evolution of the human brain, meant to keep us safe and prevent us from wandering into the same types of danger repeatedly, traumatic flashbacks are incredibly vivid: "The sensory fragments of memory intrude into the present, where they are literally relived" (Van der Kolk 2014, p. 66). When Feyre feels the ceiling and the walls closing in on her, even though she has survived the second challenge, she is reliving the traumatic experience in a way that is an accurate representation of post-traumatic flashbacks. Further, Feyre feels disembodied in these moments. Van der Kolk describes the "extreme disconnection from the body that so many people with histories of trauma and neglect experience" (p. 91), giving examples of patients who could not identify daily objects that they touched with their eyes closed.

For the third task, Amarantha forces Feyre to execute three faeries. Knowing that her own life is forfeit if she refuses, Fayre reluctantly stabs the first two with daggers. The third figure is Tamlin, her beloved, but Feyre pieces together earlier clues that his heart is made of stone, and thus she can stab him without killing him. Amarantha, infuriated by Feyre actually completing all three tasks, begins to assault Feyre with her magic: "My very bones were shattering as my body rose and then slammed onto the hard floor, and I was crushed beneath another wave of torturous agony" (Thorns and Roses, p. 399). Feyre deciphers Amarantha's final riddle in the moments before she dies, thereby lifting the spell binding Tamlin and his court; Tamlin kills Amarantha; and the seven High Lords of the faerie realm resurrect Feyre.

This is not simply trauma; this is torture porn. Readers look on as Feyre is brutalized, both physically and emotionally. Forced into spectatorship, readers may experience the same voyeuristic and even visceral response as viewers of a horror film. As to the voyeuristic/pornographic angle, Feyre's body is not eroticized, but she is made to suffer for love, and there is no refuge afforded her, so her suffering is constantly on display (another trait in common with torture porn films). In the final scene with Amarantha, Feyre is forced to hear her own ribs breaking and is prevented from blacking out so that she must continue to feel the pain (Thorns and Roses, p. 399). She dies "choking on my own blood" (Thorns and Roses, p. 403) and has an disembodied vision, through the bond with Rhysand, of her own body, "prostrate on the ground, my head snapped to one side at a horribly wrong angle" (Thorns and Roses, p. 404). The graphic and vicious nature of these descriptions is foreign to fairy tales; Feyre's torture and death bear more similarity to torture porn, snuff films and splatterpunk than to literary convention or the spoken style of oral folktales. 
Even though she is magically resurrected, the suffering is not over for Feyre, which is another accurate representation of trauma for many people. The aftermath of trauma, whether or not it is severe enough to warrant a PTSD diagnosis, can be agonizing:

We cannot concentrate or relax into a sleep that may be filled with nightmares of what we've suffered or might again undergo. Painful images of past loss and future harm recur, invading quiet moments. When trauma causes prolonged freezing, our emotional numbness may make us pull away from those to whom we've been close. (Gordon 2019, pp. 30-31)

In the second book of the series, A Court of Mist and Fury, Feyre is reunited with Tamlin at his estate in the Spring Court and they are soon to be married. However, Feyre is deeply unhappy: she suffers horrendous nightmares and throws up on a nightly basis, she is socially avoidant, she cannot abide the color red as it reminds her of the blood she has spilled, and she increasingly feels trapped and helpless (partly because she is trapped: Tamlin refuses to let her journey beyond the confines of his estate). Feyre feels she cannot confide in Tamlin nor in her friend Lucien about how bad her internal state has become, and thus she suffers alone, exhibiting most of the symptoms listed above. Indeed, the series fandom has discussed how Tamlin's behavior mimics that of Amarantha, as he becomes increasingly controlling of both Feyre and his second-in-command Lucien in an attempt to regain power (see Sarahviehmann 2016a, 2016b, "'Let Go', I Said ... " and "'Come Now, Tamlin', Rhysand ... "). The confining, controlling nature of Tamlin and Feyre's relationship in the second book is reminiscent of Gothic literature, or alternately of the abuse victim who remains entrapped in the patterns of earlier abuse, seeking out the same kinds of relationships again and again until the cycle is broken. Again, the series as a whole may be referred to as a "dark" fairy tale should one want to tap into the word's associations of something exploring the less genteel forms of human behavior and psychology, though as noted above, calling something a "dark" fairy tale is either too vague or problematic for its racial connotations. At the very least, this series does not distinguish between "light" and "dark" fae or Seelie and Unseelie faerie courts as other works do, nor does it seem to associate light-skinned characters with good and dark-skinned characters with evil, though most of the protagonists seem to be on the fairer-skinned side. Evil, this series implies, may live within the hearts of anyone, mortal or fae, dark-skinned or light; but at the same time, readers are primarily given fair-skinned characters with which to empathize.

Trauma may also damage digestion, which can range from losing one's appetite and experiencing heartburn to leaky gut and digestive tract microbiome disturbances (Gordon 2019, pp. 33-39). Feyre experiences this as well, as noted above with her nightly vomiting and in her extreme weight loss, which characters supposedly close to her seem to not notice; Rhysand snidely asks Tamlin if he's run out of food (Mist and Fury, Maas 2016, p. 105), and at a later point in the narrative, Feyre takes Lucien to task for doing nothing "Even when you saw me wasting away day by day" (Mist and Fury, Maas 2016, p. 460, italics in original). The fact that Feyre's traumatic weight loss is noticed by an apparent enemy of the Spring Court-Rhysand-and not those closest to her highlights how toxic her new home is, and how much the environment prevents her from addressing and healing from her trauma. The focus on food issues is noteworthy as one area in which fairy-tale retellings are more likely to depict reality than their source texts: while many fairy tales deal with food and especially with its lack, digestion is one of the issues that many canonical fairy tales do not spend narrative detail on.

Feyre's healing begins not when she is removed from the initial site of torture, but when she is taken from Tamlin's household. That location became a place of additional trauma for her, both because she could not process the torture there, and because being physically confined was its own traumatizing act. Feyre cannot leave the estate without guards, and she compares it in a conversation with Tamlin to "drowning. And the more you do this, the more guards ... You might as well be shoving my head under the water" (Mist and Fury, p. 100, italics in original). Being confined during or after traumatizing events can itself be traumatizing; as Van der Kolk notes of his patients: "Almost all had in some 
way been trapped or immobilized, unable to take action to stave off the inevitable. Their fight/flight response had been thwarted, and the result was either extreme agitation or collapse" (p. 30). When Feyre is initially imprisoned and tortured Under the Mountain, this is traumatic; when she is afterwards confined to Tamlin's estate, this only exacerbates her trauma, trapping her in the same state as before and preventing her from healing. Further, her entrapment parallels the feeling of being trapped in the past that registers for many real-life trauma victims, calling to mind other fairy-tale intertexts such as "Sleeping Beauty" wherein the enchanted princess (and her whole household) are trapped in a castle for one hundred years or until the curse is broken.

The first turning point occurs at Feyre and Tamlin's wedding. Despite Feyre's request that red not be one of the wedding colors, there are red rose petals scattered on the path to the dais, triggering a flashback for Feyre: "A cluster of red petals loomed ahead-just like that Fae youth's blood had pooled at my feet" (Mist and Fury, Maas 2016, p. 41). Feyre's heartbeat speeds up and she fears she will vomit. As she pauses, she worries that "I would never get better, never get free of myself, of the dungeon where I'd spent three months" (Mist and Fury, Maas 2016, p. 42). Clearly stuck in a flashback, reliving the past to the detriment of the present, Feyre almost runs out on her own wedding. She is saved by Rhysand perceiving her distress through the bond of their magical bargain and teleporting in to take her away for a week as per the terms of their bargain. Rhysand gives Feyre space in which to rest, and he also insists that she learn to read. More importantly, he teaches her how to shield herself magically, as_-unlike Tamlin-he recognizes the importance of training her to use her newfound Fae magical skills. After claiming two weeks of Feyre's time in this way according to their earlier magical bargain, and slowly becoming her friend instead of her enemy, Feyre reaches a breaking point with Tamlin's new restrictions on her movements, and decides to leave Tamlin and the Spring Court.

It is important to acknowledge, too, that there was an earlier trauma to address as well: the trauma of Feyre's impoverished past. When their family lost their fortune, she watched as men hired by her father's creditors beat him, leaving him permanently crippled, and she learned to hunt in order to delay her family's starvation in harsh winter months. Indeed, this earlier trauma revolving around starvation might be linked to Feyre's later loss of appetite when processing the trauma from being tortured. After these early life experiences, Feyre was traumatized, hollow, and bitter, and that is when she killed the faerie in wolf form that initiated the first novel's "Beauty and the Beast" plot. Being at Tamlin's court before Amarantha's torture actually gave Feyre enough space to begin to heal from her early life trauma, such that she was able to come out of her emotional and physical starvation and begin to truly connect with the people around her. If she had not been granted this space to heal, it is doubtful that she would have cared enough about Tamlin and his court to risk her life to face Amarantha in order to free them. Indeed, Feyre acknowledges that one of the reasons she had initially been drawn to Tamlin was his protector nature: "A protector-that's who he was, and would always be. What $I$ had wanted when I was cold and hard and joyless; what $I$ had needed to melt the ice of bitter years on the cusp of starvation" (Mist and Fury, Maas 2016, p. 103, italics in original). Over the course of the series, Feyre and Tamlin permanently end their relationship, but his early generosity, love, and stability help her heal from her traumatized youth and position her to act selflessly and become a hero. Thus, one subtle but extremely important point to conclude here is that poverty itself is traumatizing, a conclusion that is in line with many studies documenting the debilitating effects of impoverished living (for instance, see (Bohan 2018) on how people in poverty often die 20 years earlier than their peers not in poverty). Maas is not the only fairy-tale retelling author to make this point; as Irene Visser finds in Morrison's (2012) novel Home, "Hansel and Gretel" serves as "the fairy-tale intertext accentuating this same despair of homelessness" (p. 153) that uproots its characters, traumatizing them for much of their lives until they can reconnect and heal through their sibling relationship. 
Feyre's process of healing is surprisingly in line with what modern science tells us of trauma. Van der Kolk summarizes the findings on healing trauma that go far beyond the disease model of medical treatment:

(1) our capacity to destroy one another is matched by our capacity to heal one another. Restoring relationships and community is central to restoring well-being; (2) language gives us the power to change ourselves and others by communicating our experiences, helping us to define what we know, and finding a common sense of meaning; (3) we have the ability to regulate our own physiology, including some of the so-called involuntary functions of the body and brain, through such basic activities as breathing, moving, and touching; and (4) we can change social conditions to create environments in which children and adults can feel safe and where they thrive. (p. 38)

As Van der Kolk argues, pharmacological innovations have helped many people struggling with trauma, but those interventions should be seen as a method to get people situated so they can implement the above four general principles, not as a substitution for them. Living within a fantasy novel, Feyre does not have access to pharmacological interventions (though surely there are magical drugs on the market to help with a variety of maladies), and thus she must work her way through the processes Van der Kolk describes above, which she does, with surprising adherence to them. For space reasons, I shall not summarize the remainder of the books, but will instead mention some points of connection between trauma-healing strategies and Feyre's adventures. In terms of social connections, she leaves Tamlin, becomes friends with Rhysand and eventually falls in love with him, and gains new friends in Rhysand's inner circle of faeries. In terms of learning to regulate one's body through breath and movement, Feyre becomes a warrior by learning to fight, and she also begins to have pleasurable sensual experiences with Rhysand. Finally, in terms of changing social conditions, Feyre uses her newfound abilities (physical, magical, and social) to go to war for the sake of the oppressed faeries and humans of her world, and fight for their right to live peacefully. Point by point, Feyre enacts trauma healing methods and lights the way for others, despite the almost unbearable torture she endured previously. Viewed through the lens of torture porn, this text utilizes the conventions of torture porn to depict some of the worst possible violence a human can endure, and then departs from torture porn and returns to the fairy-tale world to assert a triumphant happy ending, a journey of healing made all the more amazing due to the depths of what was (just barely) survived.

\section{Conclusions}

As the main character in a retold fairy tale, Feyre has magic at her disposal, but also metaphor and storytelling. Twice, she likens her own life to a fairy tale, focusing on captured maidens who are freed. In the first instance, Feyre has accompanied Rhysand on a task prior to them becoming lovers, but they mimic amorous activities in order to create a distraction. Feeling like she has finally come back alive, Feyre muses on feeling awake again after this encounter, how it "Made me feel as if I'd been asleep for a year, slumbering inside a glass coffin, and he had just shattered through it and shaken me to consciousness" (Mist and Fury, Maas 2016, p. 419). This reference heightens the book's intertextual links to slumbering maiden tales such as "Sleeping Beauty" and "Snow White". In the second instance, she speaks about Rhysand to a mutual friend of theirs, saying: "He thinks he'll be remembered as the villain in the story ... But ... the villain is usually the person who locks up the maiden and throws away the key ... He was the one who let me out" (Mist and Fury, Maas 2016, p. 427). By comparing herself to an imprisoned or ensorcelled heroine-while also living the part of someone formerly imprisoned, formerly forced into traumatized numbness rather like an enchanted slumber-Feyre demonstrates the kind of self-awareness and perspective that traumatized people do not always have access to, due to how trauma affects the brain. She is able to make these references, these sly intertextual nods from the author to the reader (since we have no way of knowing which fairy tales actually exist in this fictional world), precisely because she has processed 
and healed from her trauma. No longer caught in trauma's thorns, Feyre shows us the real in fairy tales by experiencing excruciating torture and trauma and emerging from the experience healed, with a newfound family, and confident in her abilities to change the world. Though her resolution comes about partially by way of magic, all of the tools that healed Feyre are available in the real world as well, a message that brings much-needed optimism cloaked in a fairy-tale happily ever after.

Feyre's triumph-and the triumph that readers vicariously experience alongside her-is one of imagination. Not only does she heal her trauma, but she also heals her imagination. To return to my introductory claims, we as a population heavily traumatized by the events of 2020 have been fixated on imagination whether through Netflix shows or kitchen experiments or crafting, and this is because the imagination is crucial to human life, and it is threatened so clearly by trauma. A more thorough examination of the relationship between folklore, literature, pop culture, and collective trauma is beyond the scope of this paper, but it is apparent that sharing experiences and socially connecting during and after difficult times aids individuals in processing social/shared traumas. While it is impossible to know without further research (such as designing a reader response survey or conducting ethnographic interviews) what exactly readers take away from fairy-tale torture porn, it seems likely that in empathizing with Feyre and her struggles, they would also gain the catharsis of watching someone overcome trauma and restore their access to imagination. As Van der Kolk writes:

Imagination is absolutely critical to the quality of our lives. Our imagination enables us to leave our routine everyday existence by fantasizing about travel, food, sex, falling in love, or having the last word - all the things that make life interesting. Imagination gives us the opportunity to envision new possibilities-it is an essential launchpad for making our hopes come true. It fires our creativity, relieves our boredom, alleviates our pain, enhances our pleasure, and enriches our most intimate relationships. When people are compulsively and constantly pulled back into the past, to the last time they felt intense involvement and deep emotions, they suffer from a failure of imagination, a loss of the mental flexibility. Without imagination there is no hope, no chance to envision a better future, no goal to reach. (p. 17)

Trauma tugs us from present to past, leaving little to no room for imagination, creativity, play, and planning. This is not to say that people who are traumatized cannot be creative; Feyre was certainly creative in her attempts to fight for some semblance of a life even before she consciously acknowledged how much healing lay ahead of her. Rather, when trauma overstays its original function as a natural response that helps us survive life-threatening conditions, it can inhibit some of the things that make us most pleasurably human.

Fairy tales, as magic mirrors that artistically distort reality rather than displaying it forthright, are not perfect vehicles for reflecting the entirety of human experience including trauma. Fairy-tale retellings in literary modes have tended to explore these gaps, leading to poetry and prose that is often called "dark", but which I argue might better be described as grim or bitter, or, in the case of texts like A Court of Thorns and Roses (Maas 2015), described as fairy-tale torture porn. These extremely graphic works are, contrary to the violence implied in the nomenclature, not solely about witnessing or vicariously experiencing damage, harm, and trauma. In this, the fairy-tale examples of torture porn depart from other genres of torture porn like those horror film texts and return to fairyland with their potential for happy endings. Indeed, these works can offer a perspective on trauma that includes reckoning with its aftermath and eventually healing from it, lessons that real-world readers can to some degree replicate if they realize how much those lessons harmonize with our understandings of trauma today.

Funding: This research received no external funding.

Institutional Review Board Statement: Not applicable. 
Informed Consent Statement: Not applicable.

Data Availability Statement: Data sharing is not applicable to this article.

Acknowledgments: I would like to thank my editor, Susan, for her unfailing support and friendship, as well as my early readers Sarah and Carina for their time.

Conflicts of Interest: The author declares no conflict of interest.

\section{References}

Basile, Giambattista, and Nancy L. Canepa. 2007. Giambattista Basile's the Tale of Tales, or, Entertainment for Little Ones. Detroit: Wayne State University Press.

Berne, Eric. 1959. The Mythology of Dark and Fair: Psychiatric Use of Folklore. The Journal of American Folklore 72: 1-13. [CrossRef]

Bohan, Suzanne. 2018. Twenty Years of Life: Why the Poor Die Earlier and How to Change Inequity. Washington, DC: Island Press.

Bonikowski, Wyatt. 2019. 'The Juniper Tree' as Primal Scene: English-Language Literary Adaptations Since 1985. Marvels E Tales 33: 235-58.

D’Amore, Laura. 2017. Vigilante Feminism: Revising Trauma, Abduction, and Assault in American Fairy-Tale Revisions. Marvels E Tales 31: 386-405.

Gaiman, Neil. 1998. Snow, Glass, Apples. In Smoke and Mirrors: Short Fictions and Illusions. New York: Avon, pp. 331-46.

Gordon, James. 2019. The Transformation: Discovering Wholeness and Healing After Trauma. New York: HarperOne.

Jay, Stacey. 2014. Princess of Thorns. New York: Random House Children's Books.

Joosen, Vanessa. 2004. Feminist Criticism and the Fairy Tale: The Emancipation of 'Snow White' in Fairy-Tale Criticism and Fairy-Tale Retellings. New Review of Children's Literature and Librarianship 10: 5-14. [CrossRef]

Jorgensen, Jeana. 2012. Sorting Out Donkey Skin (ATU 510B): Toward an Integrative Literal-Symbolic Analysis of Fairy Tales. Cultural Analysis 11: 91-120.

Kerner, Aaron Michael. 2015. Torture Porn in the Wake of 9/11: Horror, Exploitation, and the Cinema of Sensation. New Brunswick: Rutgers University Press.

Lee, Tanith. 2016. Red as Blood. In Beyond the Woods: Fairy Tales Retold. Edited by Paula Guran. New York: Night Shade Books, pp. 7-17.

Lee, Tanith. 1995. She Sleeps in a Tower. In The Armless Maiden and Other Tales for Childhood's Survivors. Edited by Terri Windling. New York: Tor Books, pp. 42-45.

Levy, Michael, and Farah Mendlesohn. 2016. Children's Fantasy Literature: An Introduction. Cambridge: Cambridge University Press.

Lüthi, Max. 1982. The European Folktale: Form and Nature. Translated by John D. Niles. Bloomington: Indiana University Press.

Maas, Sarah J. 2015. A Court of Thorns and Roses. London: Bloomsbury Publishing.

Maas, Sarah J. 2016. A Court of Mist and Fury. New York: Bloomsbury.

McKinley, Robin. 1993. Deerskin. New York: Ace Books.

Morrison, Toni. 2012. Home. New York: Alfred A. Knopf.

Propp, Vladimir. 1968. Morphology of the Folktale, 2nd ed. Translated by Laurence Scott. Austin: U of Texas P. First published 1928.

Rowe, Karen. 1989. To Spin A Yarn: The Female Voice in Folklore and Fairy Tale. In Fairy Tales and Society: Illusion, Allusion, and Paradigm. Edited by Ruth Bottigheimer. Philadelphia: University of Pennsylvania Press, pp. 53-74.

Rankin, Walter. 2007. Grimm Pictures: Fairy Tale Archetypes in Eight Horror and Suspense Films. Jefferson: McFarland.

Reyes, Xavier Aldana. 2014. Body Gothic: Corporeal Transgression in Contemporary Literature and Horror Film. Gothic Literary Studies Series; Cardiff: University of Wales Press.

Sarahviehmann. 2016a. Sarah Viehmann, Xnightwolfx: Highfaelucien: ‘Let Go', I Said ... . Sarah Viehmann. June 2. Available online: sarahviehmann.tumblr.com/post/145277426267/xnightwolfx-highfaelucien-let-go-i-said (accessed on 19 December 2020).

Sarahviehmann. 2016b. Sarah Viehmann. Highfaelucien: 'Come Now, Tamlin', Rhysand ... . Sarah Viehmann. June 2. Available online: https://sarahviehmann.tumblr.com/post/145308206802/highfaelucien-come-now-tamlin-rhysand (accessed on 19 December 2020).

Schmiesing, Ann. 2016. Blackness in the Grimms' Fairy Tales. Marvels E Tales 30: 210-33.

Sexton, Anne. 1971. Transformations. Boston: Houghton Mifflin.

Short, Sue. 2006. Misfit Sisters: Screen Horror as Female Rites of Passage. New York: Palgrave Macmillan.

Tatar, Maria. 2003. The Hard Facts of the Grimms' Fairy Tales, 2nd ed. Princeton: Princeton University Press. First published 1987.

Thomas, Ebony Elizabeth. 2019. The Dark Fantastic: Race and Imagination from Harry Potter to the Hunger Games. New York: New York University Press.

Tyler, Joe, Ralph Tedesco, Joe Brusha, Al Rio, and Joe Dodd. 2006. Grimm Fairy Tales Volume 1. Horsham: Zenescope Entertainment.

Uther, Hans-Jörg. 2004. The Types of International Folktales: A Classification and Bibliography. Based on the System of Antti Aarne and Stith Thompson. 3 vols. Helsinki: Academia Scientiarum Fennica.

Van der Kolk, Bessel. 2014. The Body Keeps the Score: Brain, Mind, and Body in the Healing of Trauma. London: Penguin Books.

Visser, Irene. 2016. Fairy Tale and Trauma in Toni Morrison's Home. MELUS: Multi-Ethnic Literature of the U.S. 41: 148-64. [CrossRef]

Whitehead, Anne. 2004. Trauma Fiction. Edinburgh: Edinburgh University Press. 
Wood, Naomi. 2006. The Ugly Duckling's Legacy: Adulteration, Contemporary Fantasy, and the Dark. Marvels E Tales 20: $193-207$. Yolen, Jane. 1995. Allerleirauh. In The Armless Maiden and Other Tales for Childhood's Survivors. Edited by Terri Windling. New York: Tor Books, pp. 36-39. 